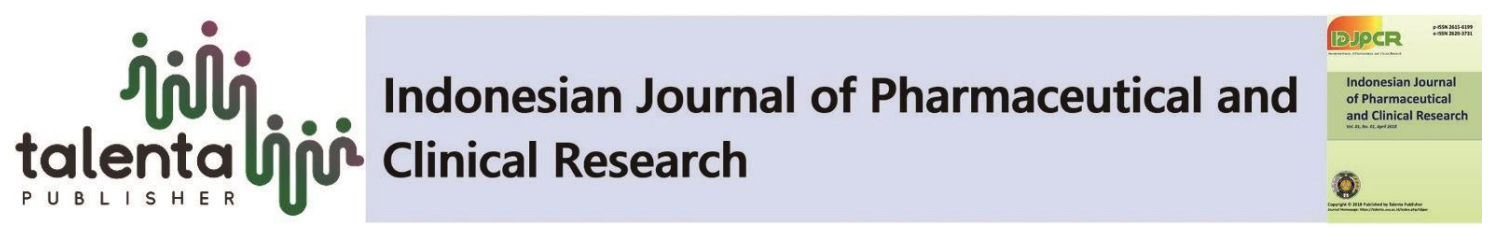

\title{
Evaluation of Supplement Consumption on North Sumatera Regional Police Headquarters Personnel
}

\author{
Munazar $^{1}$, Wiryanto ${ }^{2}$, Khairunnisa ${ }^{2}$ \\ ${ }^{1}$ Postgraduate Programs Faculty of Pharmacy, Universitas Sumatera Utara, Medan, 20155, Indonesia \\ ${ }^{2}$ Department of Pharmacology, Faculty of Pharmacy, Universitas Sumatera Utara, Medan, 20155, \\ Indonesia
}

\begin{abstract}
The purpose of his study was to determine the factors that influence the consumption pattern of supplements, and to prove the potential interactions of anticholesterol, antihypertensive, anti-uric acid, and antidiabetic drugs with supplements. This research is a descriptive research with a survey method. Data collection was carried out on 373 North Sumatera Regional Police Headquarters Personnel. This study used the dependent variable, namely the pattern of supplement consumption, while the independent variables were age, gender, health status, perception, information sources and physical activity. The results of the study using descriptive statistical tests presented using tables and percentages. The results showed that the factors that influenced the pattern of supplement consumption were male $(57.1 \%)$; $30-49$ years old $(62.5 \%)$; healthy condition $(63 \%)$; perception as a stamina enhancer $(61.7 \%)$; sources of information $(62.2 \%)$ and strenuous physical activity (49.9\%). There are synergistic interactions of anti-cholesterol drugs with supplements and antagonistic interactions of antihypertensive, anti-diabetic, anti-gout drugs with supplements.
\end{abstract}

Keywords. Evaluation, pattern consumption, supplements, potential interactions

\begin{abstract}
Abstrak. Penelitian bertujuan untuk mengetahui faktor-faktor yang mempengaruhi pola konsumsi suplemen, dan membuktikan potensi interaksi obat antikolesterol, antihipertensi, antiasam urat, dan antidiabetes dengan suplemen.Penelitian ini merupakan jenis penelitian deskriptif dengan metode survei. Pengambilan data dilakukan terhadap 373 personil MAPOLDA Sumatera Utara. Penelitian ini menggunakan variabel terikat yaitu pola konsumsi suplemen sedangkan variabel bebas adalah umur, jenis kelamin, status kesehatan, persepsi, sumber informasi serta aktivitas fisik. Hasil penelitian menggunakan uji statistik deskriptif disajikan menggunakan tabel dan persentase.Hasil penelitian menunjukkan bahwa faktor-faktor yang mempengaruhi pola konsumsi suplemen adalah jenis kelamin laki-laki (57,1\%); umur 30-49 tahun(62,5\%); kondisi sehat (63\%); persepsi sebagai penambah stamina (61,7\%); sumber informasi (62,2\%) dan aktivitas fisik berat (49,9\%). Terdapat interaksi Sinergis obat antikolesterol dengan suplemen dan interaksi antagonis obat antihipertensi, antidiabetes, anti asam urat dengan suplemen.
\end{abstract}

Kata kunci: Evaluasi, Pola Konsumsi, Suplemen, Potensi Interaksi

\footnotetext{
*Corresponding author at: Postgraduate Programs Faculty of Pharmacy, Universitas Sumatera Utara, Medan, 20155, Indonesia

E-mail address: salwafarma88@gmail.com
} 
Received 17 July 2020 | Revised 3 August 2020| Accepted 27 December 2020

\section{Introduction}

Supplements are products intended to complement the nutritional needs of food, containing one or more ingredients in the form of vitamins, minerals, amino acids or other ingredients (derived from plants or non-plants) that have nutritional value and or physiological effects in concentrated amounts [1]. The use of supplements needs to pay attention to the rules of use. In addition, supplements only work for those who really need them. If a person gets adequate food sources, exercise, adequate rest and sleep, regular life, it is not advisable to take supplements [2]. Many people take supplements in large doses only because of personal perception and the influence of advertising rather than based on scientific experience regarding the advantages and disadvantages of using the supplement. Taking supplements is not wrong, but what needs to be paid attention is that their use must be adjusted according to needs because excessive consumption will interfere with health [3]. Excessive use of supplements will not provide benefits, but actually endanger health [4]. Some supplements taken with medication can cause adverse symptoms. The interaction between drugs and supplements can affect the effectiveness of the drugs that are being consumed [5]. The Police of the Republic of Indonesia is a government agency that has the main task of maintaining security and public order, enforcing the law, providing protection, protection and services to the community. North Sumatera Regional Police Headquarters Personnel are part of the Indonesian National Police and are expected to always appear prime (healthy physical and spiritual) in carrying out their duties. And the health of personnel is also controlled every year in the Periodic Health Examination work program, namely physical and laboratory examinations. Based on the results of these examinations from 2017 and 2018 it was found that there were several diseases including cholesterol, hypertension, gout and diabetes. Given the many activities or demands of a job and having a variety of physical activities, many of the North Sumatera Regional Police Headquarters Personnel take supplements without paying attention to proper and correct usage rules. When viewed from the data on the planned needs of the North Sumatera Regional Police Headquarters Polyclinic every year, the number of requests for supplements is the most in addition to other drugs. Based on the description above, this research will evaluate the consumption patterns of supplements for the North Sumatera Regional Police Headquarters Personnel.

\section{Materials and Methods}

\subsection{Research Design}

This study was conducted to evaluate the consumption patterns of the North Sumatera Regional Police Headquarters personnel, totaling 5,557 personnel. The independent variables in this study 
are the factors that influence the consumption of supplements, namely age, gender, health status, perception, information sources and physical activity. The dependent variable is the consumption pattern and potential supplement interactions. The parameter in this study is the consumption pattern based on the relationship between the frequency of consumption and the usage rules

\subsection{Research Location}

The research was conducted on Jl. Sisingamangaraja Km 10.5 Tanjung Morawa North Sumatera Regional Police Headquarters.

\subsection{Population}

The population of this research is North Sumatera Regional Police Headquarters Personnel, amounting to 5,557 personnel.

\subsection{Parameters Analysis}

Data collection was carried out through interviews in the form of distributing questionnaires to North Sumatera Regional Police Headquarters Personnel. Then do the stages of coding data, editing data, creating data structures, entering data, cleaning and data management.

The data is first processed by testing the quality of the data through the validity and reliability tests.

\section{a. Validity Test}

Validity testing is intended to find out how carefully a test performs its measurement function so that the data collected is reliable data.

\section{b. Reliability Test}

Reliability testing is intended to determine the consistency of the answers of respondents so that the seriousness of the answers can be trusted.

\subsection{Data testing parameters performed are as follows:}

Description analysis includes several descriptive statistics such as frequency and descriptive.

\section{Results And Discussion}

From the distribution of questionnaires to 373 North Sumatera Regional Police Headquarters Personnel, interviews were obtained as in the following table below: 


\subsection{Factors that influence the consumption pattern of supplements North Sumatera Regional Police Headquarters Personnel}

Table 1. Characteristics of Supplement Consumption of the North Sumatera Regional Police Headquarters Personnel

\begin{tabular}{|c|c|c|}
\hline Characteristics & Total & Percentage $(\%)$ \\
\hline \multicolumn{3}{|l|}{ Gender : } \\
\hline Male & 213 & 57.1 \\
\hline Female & 160 & 42.9 \\
\hline \multicolumn{3}{|l|}{ Age: } \\
\hline 19-29 years old & 97 & 26.0 \\
\hline $30-49$ years & 233 & 62.5 \\
\hline 50-64 years & 43 & 11.5 \\
\hline \multicolumn{3}{|l|}{ Health: } \\
\hline Healthy / fit & 103 & 63 \\
\hline Limp condition & 103 & 27.6 \\
\hline Sick & JJ & 9.4 \\
\hline \multicolumn{3}{|l|}{ Perception: } \\
\hline \multicolumn{3}{|l|}{ Increase Stamina / Fit / } \\
\hline Prime & 230 & 61.7 \\
\hline Additional Food & 104 & 27.9 \\
\hline Treating Disease & 39 & 10.4 \\
\hline \multicolumn{3}{|l|}{ Resources : } \\
\hline Doctor / Pharmacist's & 232 & 62.2 \\
\hline \multicolumn{3}{|l|}{ Prescription } \\
\hline $\begin{array}{l}\text { Mass Media } \\
\text { advertisements }\end{array}$ & 70 & 18.8 \\
\hline Friends / Family & 71 & 19.0 \\
\hline \multicolumn{3}{|l|}{ Physical activity: } \\
\hline Light & 33 & 8.8 \\
\hline Is & 154 & 41.3 \\
\hline Weight & 186 & 49.9 \\
\hline
\end{tabular}

Based on Table 1 of the data on the characteristics of the research results on the factors that influence the consumption pattern of North Sumatera Regional Police Headquarters Personnel. it is found that the sex factor of male respondents consumed more supplements (57.1\%) this could be due to the respondent's gender at the time of the study. more men than women. The female sex prefers supplements for appearance or beauty while men prefer to maintain stamina [6]. Male athletes consume more supplements. Then for the age factor, the average respondent who consumed the most supplements was 30-49 years old (62.5\%) [7]. The age affects a 
person's speed in receiving and responding to information received and is one of the factors related to preference for supplement consumption [8]. Balanced nutrition, the age group of 3049 years was a age group that requires a lot of calories [9]. Furthermore, from the results of the study, it can be seen that the most respondents who consume supplements to North Sumatera Regional Police Headquarters Personnel.are when their bodies are in a healthy / fit condition (63\%) where North Sumatera Regional Police Headquarters Personnel, often ask doctors to prescribe supplements to support their physical activity. This is in line with the survey results regarding the reason most respondents consume supplements is to maintain stamina / fitness / in order to appear prime $(61.7 \%)$. The goal of consuming supplements is to increase fitness and stamina.Then the data on the source of information showed that the consumption of supplements [10]. The North Sumatera Regional Police Headquarters Personnel obtained the most information from doctor's prescriptions and pharmacist suggestions, namely $62.2 \%$. This is because North Sumatera Regional Police Headquarters Personnel often visit the Polyclinic to ask for a doctor's prescription and pharmacist advice to be given supplements that can support their physical activity. From the physical activity data, it was found that most respondents in consuming supplements were during strenuous activity around $49.9 \%$. The use of supplements is more in individuals who are physically active, individuals who exercise regularly at least three times a week are more likely to use supplements. Every physical activity requires energy to move [11]. Workers who have strenuous activities tend to use supplements [12].

\subsection{Potential Drug Interactions with Supplements in North Sumatera Regional Police Headquarters Personnel}

Drug interactions are drug effects caused when two or more drugs interact and can affect the body's response to treatment [13]. Drug interactions are one type of problem related to drugs. The use of drugs in conjunction with supplements has the potential to change the effect of the drugs being consumed either to increase the effect or actually decrease the effect of the drug being consumed. Interaction of Anti Cholesterol Drugs with Supplements in North Sumatera Regional Police Headquarters Personnel can be seen in table 2.

Table 2. The anti-cholesterol (Atorvastatin) consumed by North Sumatera Regional Police Headquarters Personnel together with supplements

\begin{tabular}{llcc}
\hline \multicolumn{1}{c}{ Types of drugs with supplements } & $\begin{array}{l}\text { Number of } \\
\text { (Personnel) }\end{array}$ & $\mathrm{n}$ & Percentage \\
\hline Avesco (atorvastatin) + Calcifar Plus & & & \\
\hline Avesco (atorvastatin) + CDR FORTOS & 6 (Personnels) & 373 & $1.6 \%$ \\
\hline $\begin{array}{l}\text { Avesco (atorvastatin) + Santa.E } \\
\text { (vitamin.E) }\end{array}$ & & & \\
\hline
\end{tabular}

Based on the table 2 above, data are obtained from 6 respondents or $1.6 \%$ who consumed avesco (atorvastatin) with supplements. The consumption of the anti-cholesterol drug 
atorvastatin together with CALCIFAR PLUS and CDR supplements containing calcium and vitamin $\mathrm{D}$ involves an interaction between atorvastatin and vitamin $\mathrm{D}$, which has a synergistic effect on lowering cholesterol levels, where vitamin D inhibits HMG-Coa reductase. Vitamin D is needed to activate CYP3A4, an enzyme from cytochrome P450 that metabolizes atorvastatin into major metabolites. Vitamin D increases atorvastatin levels to be more effective at lowering cholesterol levels [14]. From 16 respondents, it was found that giving atorvastatin together with Vitamin D could reduce total cholesterol levels by $157 \pm 37 \mathrm{mg} / \mathrm{dl}$ and giving atorvastatin without vitamin D supplementation reduced total cholesterol levels by $169 \pm 35 \mathrm{mg} / \mathrm{dl}$. [15]

The concurrent consumption of Avesco (Atorvastatin) with Santa E containing Vitamin E involves a synergistic interaction between atorvastatin and vitamin $\mathrm{E}$ through the mechanism of increasing FMD endothelium in the brachial artery and vasodilation in hypercholesterolemic patients so that the administration of these drugs and supplements is more effective at lowering cholesterol in the blood [16].

Based on the results of this study, there is a potential for a synergistic interaction between the anti-cholesterol drug Atorvastatin and supplements containing Vitamin D, as well as the consumption of atorvastatin with Vitamin $\mathrm{E}$, there is also a potential for synergistic interactions to reduce blood cholesterol levels.

Interaction of Antihypertensive Drugs with Supplements in North Sumatera Regional Police Headquarters Personnel can be seen in table 3.

Table 3. Data on the antihypertensive drug (Amlodipine) consumed by North Sumatera Regional Police Headquarters Personnel together with supplements

\begin{tabular}{llll}
\hline \multicolumn{1}{c}{ Types of drugs with supplements } & $\begin{array}{l}\text { Number of } \\
\text { (Personnel) }\end{array}$ & $\mathrm{n}$ & Percentage \\
\hline Amlodipin + CDR FORTOS & & & \\
\hline Amlodipin + Calcium Laktat & 5 Personnels & 373 & $1.34 \%$ \\
\hline
\end{tabular}

Based on Table 3 above, data is obtained that there are 5 respondents with a percentage of $1.34 \%$ who consume the antihypertensive drug Amlodipine with calcium lactate supplements and CDR Fortos. Concomitant consumption of Amlodipine with CDR Fortos containing calcium and vitamin D involves interactions. Amlodipine works by lowering arterial blood pressure by inhibiting the entry of calcium ions into cells. Taking calcium-containing supplements can facilitate extrusion / excretion of calcium in smooth muscle. However, one hand, giving calcium can cause an antagonistic effect of amlodipine, where calcium can weaken the effect or action of amlodipine when consumed in the long term [17].

Interaction of Antidiabetic Drugs with Supplements in North Sumatera Regional Police Headquarters Personnel can be seen in table 4. 
Table 4. Data on the Antidiabetic (Metformine) consumed by North Sumatera Regional Police Headquarters Personnel together with supplements

\begin{tabular}{cccc}
\hline $\begin{array}{c}\text { Types of drugs with } \\
\text { supplements }\end{array}$ & $\begin{array}{c}\text { Number of } \\
\text { (Personnel) }\end{array}$ & $\mathrm{n}$ & Percentage \\
\hline Metformin + Pritavit & 4 Personnels & 373 & $1.07 \%$
\end{tabular}

Based on table 4 the results showed that there were 4 respondents with a percentage of $1.07 \%$ who consumed the antidiabetic drug metformin with Pritavit supplements. Metformin consumption for a long time causes decreased levels of vitamin B12. If there is a deficiency of vitamin B12, homocysteine levels in plasma will increase the risk of blockage of blood vessels and neuropathy [18]. The consumption of Pritavit supplements containing vitamin B12 by North Sumatera Regional Police Headquarters Personnel can reduce the risk of neuropathy. Meanwhile, Pritavit contains vitamin B3 or niacin which can inhibit the liver triglyceride synthesis, increased availability of free fatty acids can stimulate hepatic glucose output directly or indirectly [19]. Free fatty acids are known to stimulate glucogenesis [20]. Niacin also plays a role in decreasing insulin sensitivity, as a result of rebounding free fatty acids [21]. In addition to triggering insulin resistance, the rebound process of free fatty acids by niacin can also cause pancreatic beta cell dysfunction. Meanwhile, the pharmacodynamics of metformin are by reducing hepatic glucose production, reducing intestinal glucose absorption and improving insulin sensitivity by increasing the uptake and use of peripheral glocci. Taking metformin with supplements containing vitamin B3 (niacin) can lead to potential antagonist interactions reducing the effectiveness of metformin.

Interaction of Anti Uric Acid Drugs with Supplements in North Sumatera Regional Police Headquarters Personnel can be seen in table 4.

Table 5. Data on the Anti Uric Acid drug (Allopurinol) consumed by North Sumatera Regional Police Headquarters Personnel along with supplements

\begin{tabular}{llll}
\hline $\begin{array}{c}\text { Types of drugs with } \\
\text { supplements }\end{array}$ & $\begin{array}{c}\text { Number of } \\
\text { (Personnel) }\end{array}$ & $\mathrm{n}$ & Percentage \\
\hline Allupurinol + Pritavit & & & \\
\hline Allupurinol + enervon.C & 4 (Personnel) & 373 & $1.07 \%$
\end{tabular}

Based on Table 5 data obtained from 4 respondents who took the anti-uric acid drug Allupurinol with Pritavit and Enervon C supplements. Consumption of anti-uric acid drugs together with supplements caused potential interactions that could reduce the effectiveness of allupurinol. Concurrent consumption of Allopurinol with Pritavit (vitamins B1, B2, B3, B6, B12 and vitamin $\mathrm{C}$ ) involves the interaction of allopurinol antagonists with vitamin B3 (niacin) which 
will reduce the effectiveness of allopurinol, where niacin reduces uric acid excretion in the urine. which can increase uric acid levels by $14 \%$ and worsen pre-existing gout. Niacin can increase urate reabsorption in the kidney as a counter ion in uric acid and increase the rate of purine biosynthesis [22].

\section{Conclusion}

The conclusion of this study is factors affecting supplementation on Sumatera Police Headquarters personnel is factor male sex (57.1\%), aged 30-49 years (62.5\%), healthy / fit (63\%), perception as a stamina enhancer (61.7\%), source of information on doctor's prescription / pharmacist advice (62.2\%) and strenuous physical activity (49.9\%) and thereare interactions of anti-cholesterol, antihypertensive, anti-uric acid drugs with supplements. For antidiabetic drugs there are no drug interactions with supplements. the researchers hope to the personnel to pay more attention to supplements and drugs consumed.

\section{REFERENCES}

[1] B. Carratù and S. Giammarioli, "Food Supplements Containing Botanicals: The Concept of Quality," Food Supplements Containing Botanicals: Benefits, Side Effects and Regulatory Aspects, pp. 179-195, 2017.

[2] V. Dobrovolskij, "Prevalence of food supplement use and opinion about food supplements among Lithuanian residents," European Journal of Public Health, vol. 28, no. supplement 4, 2018.

[3] Anonym, "Food supplements," Food Law: Policy \& Ethics, pp. 272-274, Jun. 2001.

[4] A. Perelson and L. Ellenbogen, "Rationale for Use of Vitamin and Mineral Supplements," Handbook of Nutrition and Food, 2001.

[5] Arcy PF. "Adverse Drug Reaction Update," Adverse Drug Reactions and Toxicological Reviews, vol. 21, no. 1-2, pp. 113-120, 2002.

[6] C. Rona and E. Berardesca, "Aging skin and food supplements: the myth and the truth," Clinics in Dermatology, vol. 26, no. 6, pp. 641-647, 2008.

[7] A. Sato, A. Kamei, E. Kamihigashi, M. Dohi, Y. Komatsu, T. Akama, and T. Kawahara, "Use of Supplements by Young Elite Japanese Athletes Participating in the 2010 Youth Olympic Games in Singapore," Clinical Journal of Sport Medicine, vol. 22, no. 5, pp. 418-423, 2012.

[8] "Low carbohydrate information, consumer health preferences and market demand of fruits in the United States," The Applied Economics of Weight and Obesity, pp. 110114, 2016.

[9] RI. Permenkes, “Angka Kecukupan Gizi yang Dianjurkan Bagi Bangsa Indonesia”. 2013

[10] L. Bergstrom, "The Use of Multiple Dietary Supplements," Journal of Dietary Supplements, vol. 6, no. 1, pp. 1-8, 2009.

[11] B. J. Lyle, J. A. Mares-Perlman, B. E. K. Klein, R. Klein, and J. L. Greger, "Supplement Users Differ from Nonusers in Demographic, Lifestyle, Dietary and Health Characteristics," The Journal of Nutrition, vol. 128, no. 12, pp. 2355-2362, 1998.

[12] J. L. Greger, "Dietary Supplement Use: Consumer Characteristics and Interests," The Journal of Nutrition, vol. 131, no. 4, p. 1339S-1343S, 2001.

[13] H.G. Yasin, M.J. Mejaya, F. Kasim and Subandi, "Development of Quality Protein Maize (QPM) In Indonesia". Proceedings of The Ninth Asian Regional Maize Workshop. Beijing. China, p. 282, 2005. 
[14] C. S. Thummel, "Molecular Mechanisms of Developmental Timing in C. elegans and Drosophila," Developmental Cell, vol. 1, no. 4, pp. 453-465, 2001.

[15] J. Schwartz, "Effects of Vitamin D Supplementation in Atorvastatin-Treated Patients: A New Drug Interaction With an Unexpected Consequence," Clinical Pharmacology \& Therapeutics, vol. 85, no. 2, pp. 198-203, 2008.

[16] T. Neunteufl, R. Katzenschlager, A. Hassan, U. Klaar, S. Schwarzacher, D. Glogar, P. Bauer, and F. Weidinger, "Systemic endothelial dysfunction is related to the extent and severity of coronary artery disease," Atherosclerosis, vol. 129, no. 1, pp. 111-118, 1997.

[17] A. Antony, "Amlodipine Abridged Calcium Associated Complex-I Inhibition in 6OHDA Lesioned Parkinson's Rat," British Journal of Pharmaceutical Research, vol. 4, no. 10, pp. 1269-1275, 2014.

[18] M. A. Ahmed, G. Muntingh, and P. Rheeder, "Vitamin B12 deficiency in metformintreated type-2 diabetes patients, prevalence and association with peripheral neuropathy," BMC Pharmacology and Toxicology, vol. 17, no. 1, 2016.

[19] S. H. Ganji, V. S. Kamanna, and M. L. Kashyap, "Niacin and cholesterol: role in cardiovascular disease (review)," The Journal of Nutritional Biochemistry, vol. 14, no. 6, pp. 298-305, 2003.

[20] S. Tavintharan and M. L. Kashyap, "The benefits of niacin in atherosclerosis," Current Atherosclerosis Reports, vol. 3, no. 1, pp. 74-82, 2001.

[21] G. L. Vega, N. B. Cater, S. Meguro, and S. M. Grundy, "Influence of ExtendedRelease Nicotinic Acid on Nonesterified Fatty Acid Flux in the Metabolic Syndrome With Atherogenic Dyslipidemia," The American Journal of Cardiology, vol. 95, no. 11, pp. 1309-1313, 2005.

[22] C. Ben Salem, R. Slim, N. Fathallah, and H. Hmouda, "Drug-induced hyperuricaemia and gout," Rheumatology, p. kew293,2016. 